Medicine. 98(42), tr. e17635-e17635.

4. Tyloch, Janusz F. và Wieczorek, Andrzej Paweł (2017), "The standards of an ultrasound examination of the prostate gland. Part 2", Journal of ultrasonography. 17(68), tr. 43-58.

5. Yoo, Eun Sang và các cộng sự. (2011), "The impact of overactive bladder on health-related quality of life, sexual life and psychological health in Korea", International neurourology journal. 15(3), tr. 143-151.

6. Wein, Alan Jvà các cộng sự (2016), " Benign Prostatic Hyperplasia: Étiology, Pathophysiology, Epidemiology, and Natural History", CampbellWalsh Urology 4(Chapter 103), tr. 2425-2461.

\title{
MộT Số ĐẶC ĐIỂM DỊCH TỄ HỌC SỐT XUẤT HUYẾT Ở KHÁNH HÒA 2017-2018
}

\section{Vũ Xuân Nghĩa ${ }^{1}$, Nguyễn Văn Chuyên ${ }^{2}$, Nguyễn Quang Bình ${ }^{3}$, Nguyễn Hải Sâm ${ }^{2}$, Phan Quốc Hoàn ${ }^{1}$, Nguyễn Thị Hiền ${ }^{4}$}

\section{TÓM TẮT.}

Nghiên cứu được thực hiên 100 bệnh nhân mắc bênh sốt xuất huyểt trên địa phận Nha Trang, Khánh Hò̀a. Phương pháp nghiên cứu mô tả cắt ngang, labo. Kết quả nghiên cứu cho thây, tỉ lệ nhóm người mắc bệnh sốt xuất huyết tâp trung ở trẻ em $21 \%$ và người già $20 \%$. Nguyên nhẩn gây bệnh sốt xuất huyết có virus Dengue $9 \%$ khi phát hiện bằng test nhanh nsp1.

Tư khóa: Sốt xuất huyết, virus Dengue.

\section{SUMMARY}

\section{SOME CHARACTERISTICS OF HEMORRHAGE FEVER IN KHANH HOA 2017-2018}

The study was performed on 100 patients suffering from hemorrhagic fever in Nha Trang, Khanh Hoa. The method describes cross section, labo. Research results show that the proportion of people with hemorrhagic fever concentrates in children $21 \%$ and the elderly $20 \%$. Causes of hemorrhagic fever with dengue virus $9 \%$ when detected by rapid test nsp 1 .

Keywords: hemorrhagic fever, Dengue virus

\section{I. ĐĂT VẤN ĐỀ}

Khánh Hòa là một tỉnh ở vùng duyên hải cực Nam Trung Bộ, nằm trong khu vực khí hậu nhiệt đới xa van. Khánh Hòa Thường chỉ có 2 mùa rõ rệt là mùa mưa và mùa nắng. Mùa mưa ngắn, từ khoảng giữa tháng 9 đến giữa tháng 12, lượng mưa thường chiếm trên $50 \%$ lượng mưa trong năm. Những tháng còn lại là mùa nẳng. Nhiệt độ trung bình hàng năm của Khánh Hòa cao khoảng $26,7^{\circ} \mathrm{C}$, độ ẩm tương đối khoảng $80,5 \%$. Đây cũng coi là điều kiện môi trường, thời tiết khí hậu

\footnotetext{
${ }^{1}$ Bênh viện TWQĐ108

${ }^{2}$ Họ viện Quân $y$

${ }^{3}$ Bệnh viện Răng Hàm Mặt TW

${ }^{4}$ Đai hoc Dước Hà Nôi.

Chịu trách nhiệm chính: Vũ Xuân Nghĩa

Email: nghia69@gmail.com

Ngày nhânn bài: 27.10.2020

Ngày phản biên khoa học: 27.11.2020

Ngày duyệt bài: 9.12.2020
}

phù hợp với quá trình phát triển của mỗi, vector mang các mầm bệnh gây bệnh sốt xuất huyết.

Bệnh sốt xuất huyết thường gây bởi virus Dengue hay còn gọi sốt xuất huyết Dengue. Song những năm gần đây, tại Khánh Hòa cho thây tính chất phức tập của bệnh sốt xuất huyết về quy mô, tần số, mức độ trầm trọng của bệnh. Nguyên nhân gây bệnh sốt xuất huyết hiện nay tập trung vào 03 mầm bệnh chính là virus Dengue, Virus Chikungunya, virus Zika. Để làm sóng tỏ về nguyên nhân gây bệnh sốt xuất huyết ở Khánh Hòa, chúng tôi tiến hành nghiên cứu một số đặc điểm dịch tễ học của bệnh sốt xuất huyết, từ đó đánh giá việc lưu hành nguyên nhân gây bệnh sốt xuất huyết.

\section{II. ĐỐI TƯỢNG VÀ PHƯƠNG PHÁP NGHIÊN CỨU}

2.1. Đối tượng nghiên cứu: Gồm 100 bệnh nhân được chẩn đoán sơ bộ sốt xuất huyết trên địa bàn Nha Trang từ 2017-2018.

2.2. Phương pháp nghiên cứu. Thiết kế nghiên cứu nghiên cứu cắt ngang, labo, nhận xét đánh giá.

Xây dựng tiêu chuẩn lựa chọn bênh nhân sốt xuất huyết theo thứ tư ưu tiên: Xuất huyết (dấu hiệu dây thắt (+) hoặc xuất huyết tự nhiên); Sốt cao, kéo dài từ 2-7ngày. (lấy mẫu tốt nhất thường trong 5 ngày đầu khi khởi phát các triệu chứng đầu tiên); Đau đầu, đau cớ, đau khớp; Giảm tiểu câu < $100.000 / \mathrm{mm}^{3}$, Hematocrit tăng; Các bệnh nhân được chẩn đoán ngoài cộng đồng dựa vào test nhanh và Kit ELISA; Sống trong vùng có dịch lưu hành.

Phương pháp phát hiện virus bao gồm ELISA, Realtime RT-PCR, thực hiện theo hướng dẫn của nhà sản xuất.

2.3. Xử lý số liệu: phần mềm Exel.

2.4. Y đức: Những bệnh nhân đều chấp thuận tham gia nghiên cứu, mọi kết quả mang tính cá nhân được thông báo và bảo mật theo quy định. 


\section{KẾT QUẢ NGHIÊN CỨU VÀ BÀN LUẬN}

\section{1. Đặc điểm bệnh nhân nghiên cứu}

Bảng 1: Đặc điểm tuổi và giới

\begin{tabular}{|c|c|c|c|c|c|c|}
\hline \multirow{2}{*}{ Tuổi Giới } & \multicolumn{2}{|c|}{ Nam } & \multicolumn{2}{c|}{ Nữ } & \multicolumn{2}{c|}{ Tổng } \\
\cline { 2 - 8 } & $\mathbf{n}$ & $\mathbf{0}$ & $\mathbf{n}$ & $\mathbf{\%}$ & $\mathbf{n}$ & $\mathbf{\%}$ \\
\hline$<10$ & 15 & $15 \%$ & 6 & $6 \%$ & 21 & $21 \%$ \\
\hline $11-20$ & 10 & $10 \%$ & 5 & $5 \%$ & 15 & $15 \%$ \\
\hline $21-30$ & 9 & $9 \%$ & 4 & $4 \%$ & 13 & $13 \%$ \\
\hline $31-40$ & 4 & $4 \%$ & 8 & $8 \%$ & 12 & $12 \%$ \\
\hline $41-50$ & 4 & $4 \%$ & 4 & $4 \%$ & 8 & $8 \%$ \\
\hline $51-60$ & 12 & $12 \%$ & 8 & $8 \%$ & 20 & $20 \%$ \\
\hline$>60$ & 7 & $7 \%$ & 4 & $4 \%$ & 11 & $11 \%$ \\
\hline Tổng & $\mathbf{6 1}$ & $61 \%$ & $\mathbf{3 9}$ & $39 \%$ & $\mathbf{1 0 0}$ & $100 \%$ \\
\hline
\end{tabular}

Nhận xét: Kết quả trên cho thấy, nhóm bệnh nhân bị mắc sốt xuất huyết rơi vào nhóm trẻ em (21\%) và người già (20\%). Điều này cho thấy, các yếu tố nguy cơ là rất cao và khả năng đáp ứng chống lại mầm bệnh của hai nhóm đối tượng này rất hạn chế.

\subsection{Kết quả lâm sàng, cận lâm sàng bệnh nhân SXH}

Bảng 2: Kêt quả biểu hiện kiểu sốt

\begin{tabular}{|c|c|c|c|c|c|c|c|c|c|c|c|c|}
\hline Kiểu sốt & \multicolumn{2}{|c|}{ Cao, đột ngột } & \multicolumn{2}{c|}{ Liên tục } & \multicolumn{2}{c|}{ Hai pha } & \multicolumn{2}{c|}{ Gai rét } & \multicolumn{2}{|c|}{ Vã mồ hôi } & \multicolumn{2}{|c|}{ Khác } \\
\cline { 2 - 12 } & $\mathbf{n}$ & $\mathbf{\%}$ & $\mathbf{n}$ & $\mathbf{\%}$ & $\mathbf{n}$ & $\mathbf{\%}$ & $\mathbf{n}$ & $\mathbf{\%}$ & $\mathbf{n}$ & $\mathbf{\%}$ & $\mathbf{n}$ & $\mathbf{\%}$ \\
\hline $\begin{array}{c}\text { Số lượng, } \\
\text { tần suất }\end{array}$ & 77 & 84 & 12 & 13 & 0 & 0 & 1 & 1,08 & 1 & 1,08 & 1 & 1,08 \\
\hline
\end{tabular}

Nhận xét: Kết quả của kiểu sốt cũng phản ánh rõ đặc điểm tính chất của bệnh sốt xuất huyết. tỉ lệ biểu hiện sốt cao, đột ngột chiếm đa số (84\%), trong khi đó các nhóm sốt khác không có hoặc biểu hiện ít.

Bảng 3: Kêt quả Hematocrit

\begin{tabular}{|c|c|c|}
\hline \multirow{2}{*}{ Giá trị khoảng Nhóm } & \multicolumn{2}{|c|}{ HEMATOCRIT } \\
\cline { 2 - 3 } & $\mathbf{n}$ & $\mathbf{\%}$ \\
\hline$<37$ & 6 & 6.0 \\
\hline $37-52$ & 66 & 66.0 \\
\hline$>52$ & 28 & 28.0 \\
\hline Tổng & $\mathbf{1 0 0}$ & $\mathbf{1 0 0 . 0}$ \\
\hline
\end{tabular}

Nhân xét: Kết quả về Hematorit ở bảng 3 cho thấy, tî̉ lệ có giá trị bình thường chiếm cao nhất $66 \%$. Nhưng tỉ lệ tăng Hematocrit cũng xảy ra chiếm $28 \%$. Đây là dấu hiệu cảnh báo cho thấy có tác động của xuất huyết, cần dự phòng kịp thời chống gây rối loạn vận mạch cho bệnh nhân.

Bảng 4: Kết quả Tiểu cầu

\begin{tabular}{|c|c|c|}
\hline \multirow{2}{*}{ Nhóm } & \multicolumn{2}{|c|}{ TIẾU CÂU } \\
\cline { 2 - 3 } Giạ khoảng X10^3 & $\mathrm{n}$ & $\%$ \\
\hline$<100$ & 9 & 9.0 \\
\hline $100-300$ & 53 & 53.0 \\
\hline Khác & 38 & 38.0 \\
\hline Tổng & $\mathbf{1 0 0}$ & $\mathbf{1 0 0 . 0}$ \\
\hline
\end{tabular}

Nhận xét: Tiểu cầu là một trong những biễn số quan trọng trong sốt xuất huyết. Sự dao động của chỉ số này phản ánh trung thành đến hiện tượng xuất huyết hoặc đe dọa xuất huyết trển bênh nhân. Giá trị ở bảng 4 cho thấy, tỉ lệ giảm tiểu cầu chiếm $9 \%$, tuy là nhỏ song cũng cho thấy cảnh báo về sự giảm tiểu cầu trên bệnh nhân sốt xuất huyết.

3.3. Kết quả phân tử trên bệnh nhân SXH

Bảng 5: Kêt quả Test nhanh NSP1 virus Dengue

\begin{tabular}{|c|c|c|}
\hline \multirow{2}{*}{ Niá trị } & \multicolumn{2}{|c|}{ NSP1 } \\
\cline { 2 - 3 } & $\mathbf{n}$ & $\mathbf{\%}$ \\
\hline Dương tính & 9 & 9.0 \\
\hline Âm tính & 89 & 89.0 \\
\hline Khác & 2 & 2.0 \\
\hline Tổng & $\mathbf{1 0 0}$ & $\mathbf{1 0 0 . 0}$ \\
\hline
\end{tabular}

Nhận xét. Để đánh giá nguyên nhân gây ra bênh sốt xuất huyết trên đia bàn, test nhanh đánh giá virus Dengue được sử dụng. Kết quả bảng 5 cho thấy, với test nhanh chỉ số NSP1, trong 100 bệnh nhân có biểu hiện sốt xuất huyết, chỉ có 9 chiếm $9 \%$ là có phản ứng với NSP1, trong khi đó tỉ lệ không phát hiện là $91 \%$. Vì đây là tầm soát nguyên nhân bằng test nhanh, do vậy kết quả này cũng chưa phản ánh hết mức độ lưu hành và gây bệnh của virus dengue. 
Bảng 6: Kêt quả phát hiện kháng thê, RNA của virus Zika và CHIK

\begin{tabular}{|c|c|c|c|c|c|c|}
\hline \multirow{2}{*}{ Giá trị Nhóm } & \multicolumn{3}{c|}{ Zika } & \multicolumn{3}{c|}{ CHIK } \\
\cline { 2 - 7 } & IgM & IgG & RNA & IgM & IgG & RNA \\
\hline Dương tính & 0 & 0 & 0 & 0 & 0 & 0 \\
\hline Âm tính & 50 & 50 & 50 & 50 & 50 & 50 \\
\hline Khác & 0 & 0 & 0 & 0 & 0 & 0 \\
\hline Tổng & $\mathbf{5 0}$ & $\mathbf{5 0}$ & $\mathbf{5 0}$ & $\mathbf{5 0}$ & $\mathbf{5 0}$ & $\mathbf{5 0}$ \\
\hline
\end{tabular}

Nhận xét: Để đánh giá sâu hơn về tình trạng gây bểnh sốt xuất huyết ở Nha Trang, các thử nghiệm về sinh học phân tử được tiến hành với hai mầm bệnh chủ yếu ngoài virus dengue, đó là virus Zika và Virus Chikungunya. Kết quả bảng 6 cho thấy, không có bệnh nhân nào phản ứng với các nghiệm pháp, hay nói cách khác, chưa phát hiện mầm bệnh Zika và CHIK trong cộng đồng sốt xuất huyết ở Nha Trang.

\section{KẾT LUÂ̂N}

Qua nghiên cứu trên 100 bệnh nhân sốt xuất huyết tại Nha Trang, kết quả cho thấy, nhóm đối tượng mắc bệnh chủ yếu ở trẻ em $(21 \%)$ và người già (20\%). Nguyên nhân gây bệnh sốt xuất huyết, phát hiện có $9 \%$ dương tính với virus Dengue, trong khi đó hoàn toàn âm tính với hai virus Zika và Chikungunya.

\section{TÀI LIẸU THAM KHẢO}

1. Endy TP, Chunsuttiwat $S$, Nisalak A, Libraty DH, Green S, Rothman AL, et al. Epidemiology of inapparent and symptomatic acute dengue virus infection: a prospective study of primary school children in Kamphaeng Phet, Thailand. American journal of epidemiology. 2002; 156(1):40-51.

2. Nisalak A, Endy TP, Nimmannitya $S$, Kalayanarooj S, Scott RM, Burke DS, et al. Serotype-specific dengue virus circulation and dengue disease in Bangkok, Thailand from 1973 to 1999. The American journal of tropical medicine and hygiene. 2003; 68(2):191-202.

3. Flipse J, Diosa-Toro MA, Hoornweg TE, Van De Pol DP, Urcuqui-Inchima S, Smit JM. Antibody-dependent enhancement of dengue virus infection in primary human macrophages; balancing higher fusion against antiviral responses. Scientific reports. 2016; 6:29201.

4. Fried $J R$, Gibbons $R V$, Kalayanarooj $S$, Thomas SJ, Srikiatkhachorn A, Yoon I-K, et al. Serotype-specific differences in the risk of dengue hemorrhagic fever: an analysis of data collected in Bangkok, Thailand from 1994 to 2006. PLoS neglected tropical diseases. 2010; 4(3):e617.

5. Chan K-S, Chang J-S, Chang $K$, Lin C-C, Huang $\mathbf{J}-\mathbf{H}$, Lin $\mathbf{W}-\mathbf{R}$, et al. Effect of serotypes on clinical manifestations of dengue fever in adults. Journal of microbiology, immunology, and infection. 2009; 42(6):471-8.

\section{PHẪU THUẬT NộI SOI TẠO HÌNH KHÚC NỐI BỂ THẬN NIỆU QUẢN THEO NGUYÊN TẮC FINNEY}

\section{TÓM TẮT}

Đặt vấn đề: Báo cáo này lần đầu tiên giới thiệu kỹ thuật nội soi tạo hình khúc nối bể thận niệu quản (KNBTNQQ) theo nguyên tắc Finney. Phương pháp: Hồi cứu 1 ca bệnh và tổng quan y văn. Kết quả: Bệnh nhân (BN) nam 4 tuổi, đưỡc chẩn đoán hẹp KNंBTNQ trái có chỉ định điều trị phẫu thuật. Chúng tối phẫu thuật nội soi ổ bụng, nhận thấy niệu quản (NQ) trái bám cao ở vị trí giữa bể thận (BT) gây gập góc làm tắc KNBTNQ. BN được rach 1 đướng mờ BT từ dưới chỗ nối BTNQ đi qua thành dưới khúc nối sang thành NQ đối diện BT. Tạo hình KNBTNQ theo nguyên

*Bệnh viện đa khoa Saint Paul

Chịu trách nhiệm chính: Trần Ngọc Sơn

Email: drtranson@yahoo.com

Ngày nhận bài: 26.10.2020

Ngày phản biện khoa học: 27.11.2020

Ngày duyệt bài: 10.12 .2020

\section{Trần Ngọc Sơn*, Dương Văn Mai*}

tắc Finney bằng cách khâu nối mép NQ với mép BT chỗ vừa mở, có đă̆t 1 dẫn lưu NQ-BT ra da. Thời gian phẫu thuật 50 phút, không có tai biến trong mổ. Sau mổ BN diễn biến ổn định, dẫn lưu được rút sau 6 ngày, thời gian nằm viện sau mổ 7 ngày.Theo dõi 8 tháng BN không có triệu chứng, siêu âm bể thận bình thường. Kết luận: Phẫu thuật nội soi tạo hình KNBTNQ theo nguyên tắc Finney là an toàn, đớn giản, thời gian phẫu thuật ngắn, có thể là một lựa chọn tốt trong điều trị tắc KNBTNQ ở trẻ em trong trường hợp niệu quản bám cao.

Tư khóa: phẫu thuật nội soi, tạo hình khúc nối bể thận niệu quản, nguyên tắc Finney

\section{SUMMARY \\ LAPAROSCOPIC PYELOPLASTY BY FINNEY'S PRINCIPLE}

Introduction: In this report, we described a new technique of laparoscopic pyeloplasty by Finney's principle. Methods: a case report and review of the 